\title{
ANALYTICAL ASSESSMENT OF LOCAL BUDGETS AND CHARGES AND MEASURES TO IMPROVE THE MECHANISMS OF THEIR MANAGEMENT
}

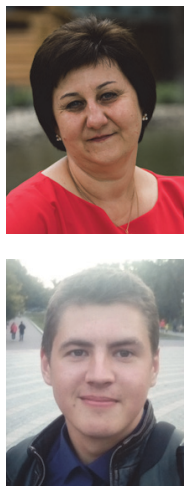

\author{
GUTSALENKO L.V., Doctor of Economics, Professor, \\ National University of Life and Environmental Sciences \\ of Ukraine \\ ORCID 0000-0001-5181-8652 \\ E-mail:lyboffv@gmail.com
}

\author{
DUBOVSKYI V.O., student of economics faculty, \\ National University of Life and Environmental Sciences \\ of Ukraine \\ E-mail:dubovskiy_vitalik@ukr.net
}

\begin{abstract}
The article examines the impact of changes in the regulatory framework on local taxes and fees. The importance of local budgets in the budget system of Ukraine is outlined. Emphasis is placed on increasing the role of local taxes and fees and increasing their share in local budgets' own revenues as the main task of the state's fiscal policy. The content of Article 10 of the Tax Code of Ukraine, which sets out a list of local taxes and fees, is based on which each village, town or city council decides on the establishment of certain local taxes and fees on its territory.

The classification of local taxes (property tax, which consists of land payment, property tax other than land, transport tax; single tax) and fees (parking fee for vehicles; tourist tax) is given. Analytical assessment of the structure of local taxes and fees of Ukraine for 20162018 has been made. It is emphasized that in the general structure of tax revenues of the local budgets the role of the tourist tax is insignificant, but there is an increase of the tourist tax in Kyiv, Odessa, Lviv and Kharkiv, which have architectural monuments, recreational infrastructure and more. Analysis of the receipt of tourist fees to the budgets of the most popular Ukrainian resorts shows that the sole leader of the rating is the balneological resort Truskavets. The most significant impact on local budget revenues is the tourist tax for the village. Polyanytsya (Bukovel Ski Resort), village. Koson (Kosino Thermal Resort), village. Novofedorivka (Black Sea resort Iron port) and the town. Skhidnytsia (balneological resort).

It is proposed to identify additional mechanisms and measures that will help to improve the budget revenue of individual local communities, the region and the country as a whole.

Generally, timely and accurate information on local taxes and fees is necessary to analyze the performance of the enterprise, which will prevent errors in the future, will allow the enterprise to optimize the tax burden and contribute to the development of the region, since taxes paid is one of the main sources financing local budgets.
\end{abstract}


Keywords: local taxes and fees, local taxation, local budget, property tax, single tax, land payment, transport tax, parking fees, tourist tax, analytical assestment, management.

\section{Actuality.}

Increasing the role of local taxes and fees and increasing their share of local government revenues is one of the main areas of strengthening local budgets and extending the financial autonomy of the respective territorial communities. The volatility of Ukraine's tax legislation drives the local tax system to change. Therefore, in order to ensure the revenue component of the budget and to set the rates of local taxes and fees, local governments should implement the principle of maximum mobility and flexibility.

Establishing an effective system of self-government oriented towards the achievement of leading countries will contribute to the creation of a proper financial base for the economic and social development of territorial communities.

\section{Analysis of recent research and publications.}

Problems related to the sources of formation of the revenue part of local budgets, in which particular attention was paid to the role of local taxation in the financial provision of powers of local governments, as well as the mechanism of their management are widely covered in the works of such leading economists as: V. Andrushchenko, O. Vasilyk, E. Zhmereko, A. Krivosaty, I. Lunina, S. Hear, V. Sutormina, V. Fedosov and others.

However, in the context of reforming and changing the local taxation system, it is possible to supplement certain mechanisms and isolate measures that will ensure the accuracy of accounting and analytical information on local taxes.

The purpose of the study is to study the impact of changes in the regulatory framework and to conduct an analytical assessment of local taxes and fees as a source of information on the status of payments on them and to identify additional mechanisms and measures that will help to improve the revenue of individual local communities, region and country as a whole.

\section{Materials and methods of research.}

In the course of the research, we used the methods of comparison, observation, analytical evaluation of calculating the deviation of the absolute values of local taxes and fees of Ukraine.

\section{The results of the study and their discussion.}

An effective and efficient system of local self-government is an important element in the functioning of a democratic state. In order to ensure the fulfillment of their functions, the creation of a proper living environment for the community, local governments should have sufficient financial resources, the basis of which is the funds of the respective budgets.

One of the important sources of revenue for local government budgets is local taxes and fees. Article 143 of the Constitution of Ukraine stipulates that local governments establish local taxes and fees. The Law of Ukraine "On Lo- 
cal Self-Government in Ukraine" states that local budgets should be sufficient to exercise the powers of local self-government bodies to provide residents of the respective communities with quality public services [4].

Increasing the role of local taxes and fees and increasing their share of local budget revenues is one of the main tasks of the state's fiscal policy. Article 10 of the Tax Code of Ukraine establishes a list of local taxes and fees, on the basis of which each village, town or city council decides on the establishment in their territory of certain local taxes and fees. Local taxes include: a property tax (consisting of a payment for land, a tax on real estate other than land, a transport tax); single tax. Local fees include: parking fee for vehicles; tourist tax. Here is a classification of this type of taxes using Fig. 1.

Local councils, within the powers defined by the Tax Code, resolve issues in accordance with the requirements set out in the Code on the establishment of property tax (in respect of property tax other than land) and the establishment of a fee for parking spaces, tourist tax. The establishment of local taxes and fees not provided for in the Tax Code is prohibited in Ukraine. Local taxes and fees shall be credited to local government budgets in accordance with Article 64 of the Budget Code of Ukraine. [5]

The reform of the territorial organization of government, which is being implemented in Ukraine today, aims to build a new model of social governance based on the creation of financially self-sufficient communities. Since 2014, Government initiatives in this area have significantly improved the financial capacity of local budgets. One proof of this is the increase in the share of local budgets' own revenues in the consolidated budget of Ukraine from $17 \%$ in 2015 to $22 \%$ in 2018. [6]

Given the changes in tax and budget legislation, the interest and direct influence of local governments on the introduction and mobilization of revenues from local taxes and fees, it is possible to clearly study the dynamics of their share in the revenues of local budgets of Ukraine (without transfers). Due to the improvement of the revenue mobilization and changes in the structure of local taxes and fees, their share in local budget revenues has increased

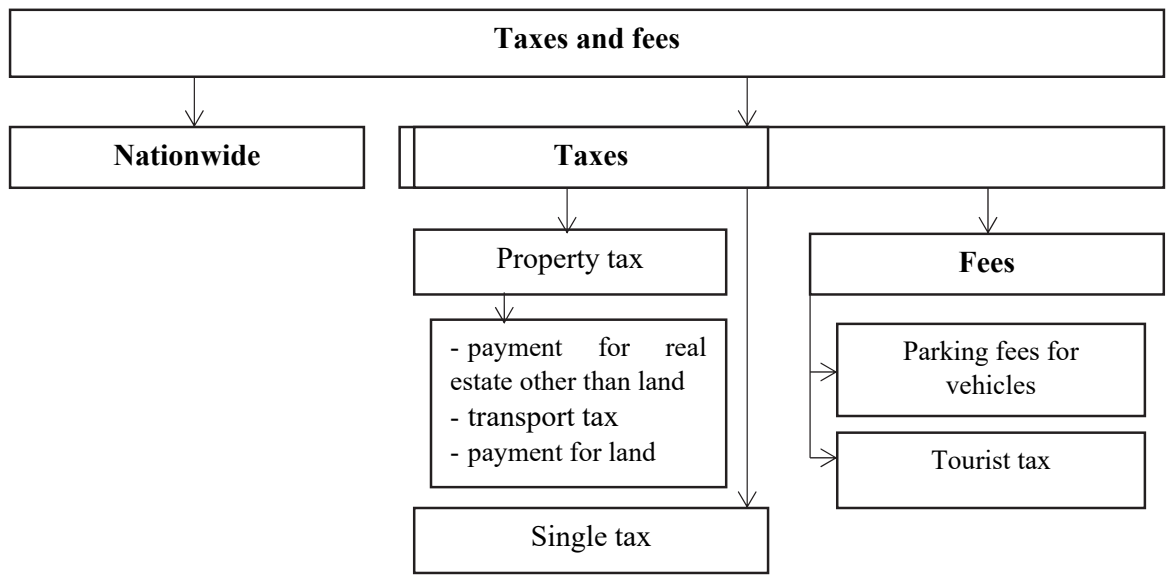

Figure 1. Composition of local taxes and fees 


\section{Structure of local taxes and fees of Ukraine}

\begin{tabular}{|l|c|c|c|c|c|c|c|c|}
\hline \multirow{2}{*}{$\begin{array}{l}\text { Types of } \\
\text { taxes }\end{array}$} & \multicolumn{2}{|c|}{2016} & \multicolumn{2}{c|}{2017} & \multicolumn{2}{c|}{2018} & \multicolumn{2}{c|}{$\begin{array}{c}\text { Deviation 2018 from } \\
2016\end{array}$} \\
\cline { 2 - 9 } & $\begin{array}{c}\text { Amount, } \\
\text { mln. }\end{array}$ & $\begin{array}{c}\text { Specific } \\
\text { weight, } \%\end{array}$ & $\begin{array}{c}\text { Amount, } \\
\text { mln. }\end{array}$ & $\begin{array}{c}\text { Specific } \\
\text { weight, } \%\end{array}$ & $\begin{array}{c}\text { Amount, } \\
\text { mln. }\end{array}$ & $\begin{array}{c}\text { Specific } \\
\text { weight, } \%\end{array}$ & $\begin{array}{c}\text { Amount, } \\
\text { mln. }\end{array}$ & $\begin{array}{c}\text { Specific } \\
\text { weight, } \%\end{array}$ \\
\hline $\begin{array}{l}\text { Total taxes } \\
\text { and fees in } \\
\text { Ukraine }\end{array}$ & 650403,5 & 100,0 & 828158,8 & 100,0 & 986348,5 & 100,0 & $+335945,0$ & x \\
\hline $\begin{array}{l}\text { Local taxes } \\
\text { and fees, } \\
\text { everything }\end{array}$ & 42261,5 & 6,5 & 52586,8 & 6,3 & 61026,4 & 6,2 & $+18764,9$ & $-0,3$ \\
\hline Property tax & 24989,4 & 3,8 & 29056,1 & 3,4 & 31272,0 & 3,2 & $+6282,6$ & $-0,6$ \\
\hline $\begin{array}{l}\text { including } \\
\text { transport tax }\end{array}$ & 246,9 & 0,04 & 245,9 & 0,03 & 314,9 & 0,03 & $+68,0$ & $-0,01$ \\
\hline $\begin{array}{l}\text { payment for } \\
\text { land }\end{array}$ & 23323,6 & 3,46 & 26384,5 & 3,07 & 9870,6 & 1,01 & $-13453,0$ & $-2,45$ \\
\hline $\begin{array}{l}\text { payment for } \\
\text { real estate } \\
\text { other than } \\
\text { land }\end{array}$ & 1418,9 & 0,3 & 2425,7 & 0,3 & 3636,0 & 0,4 & $+2217,1$ & $+0,1$ \\
\hline Single tax & 17167,1 & 2,6 & 23388,3 & 2,8 & 29564,2 & 3,0 & $+12397,1$ & $+0,4$ \\
\hline $\begin{array}{l}\text { Parking fees } \\
\text { for vehicles }\end{array}$ & 66,2 & 0,01 & 77,6 & 0,01 & 99,9 & 0,01 & $+33,7$ & - \\
\hline Tourist tax & 54,1 & 0,01 & 70,2 & 0,01 & 90,7 & 0,01 & $+36,6$ & - \\
\hline
\end{tabular}

significantly in recent years. If during $2007-2010$ their share was only $1.1 \%$ $-1.4 \%$, from 2011 to 2014 it increased to $8.8 \%$, and in 2018 it was already $24.7 \%$. The largest share in the structure of local taxes and fees is occupied by land payments $(50 \%)$ and a single tax (over 44\%). [3]

Using data from the State Budget Execution Reports of Ukraine for 20162018, we will outline in table 1 the structure of local taxes and fees.

In 2018, local governments accumulated UAH 61026.4 million, which is UAH 18764.9 million. (by $44.4 \%$ ) more than in 2017. The structure of tax revenues of local budgets shows an increase in the share of payment for real estate other than land and single tax. Compared to 2016, there are increases in local taxes and fees as a whole $(+18764.9$ million UAH) and in particular property tax $(+6282.6$ million UAH), transport tax (+68 million UAH)., payments for real estate other than land $(+\mathrm{UAH}$ 2217.1 million), single tax ( $+\mathrm{UAH}$ 12397.1 million), Fee for parking spaces (+ UAH33.7 million). ), tourist tax $(+36.6$ million $\mathrm{UAH})$.

In 2018, local budgets of Ukraine raised UAH 90.7 million in tourist tax. In the overall structure of local government tax revenues, the role of the tourist tax is negligible. This is due to the fact that, firstly, only certain territorial communities have tourist potential (architectural monuments, recreational infrastructure, etc.), and secondly, even those communities with potential do not always make full use of tourist a charge to fill their budgets.

Among the big cities - regional centers - the largest number of tourists collected in Kiev (UAH 33 million or $36.4 \%$ of the total amount of tourist tax that came to all local budgets 
in 2018), Odessa (UAH 7.3 million or $8 \%$ ), Lviv (UAH 6.5 million or 7.2\%) and Kharkiv (UAH 2.7 million or $3 \%$ ). The amount of tourist tax in other regional centers did not exceed UAH 1 million. Of course, against the background of the total amount of tax revenues to the budgets of regional centers, the tourist tax looks like a bonus, but for some cities, villages and towns - with a strong tourist or recreational potential - it is a good source of budget revenues.

Analysis of the receipt of the tourist fee to the budgets of the most popular Ukrainian resorts shows that the sole leader of the rating is the balneological resort Truskavets, where tourists paid more than 3.6 million UAH of tourist tax. But the most significant impact on local budget revenues is the tourist fee for the village. Polyanytsya (Bukovel Ski Resort) - 11\% of all tax revenues of the community budget, p. Koson (Kosino Thermal Resort) - 11\%, with. Novofedorivka (Black Sea resort Iron port) $-10 \%$ and the village. Skhidnytsia (balneological resort) - 7\%. [7].

The following measures can be practical ways of improving local taxation mechanisms in Ukraine:

- exemption for the first three years of their activity from the single taxation of newly created enterprises and entrepreneurs;

- extending the powers of local communities to introduce new local taxes and fees and administer them to businesses located locally on community lands;

- introduction of new local fees for garbage collection and disposal and others;

- when paying property tax, the basis for taxation should be the total, not the living space of all buildings except for residential, industrial and commercial use, which will enhance the principle of fairness;

- to strengthen the control over the distribution of the single tax and real income $(60 \%)$ to local budgets of village and village councils;

- to change the mechanism of collection of transport tax taking into account the territorial location of enterprises and transportation of their products independently by their own or involved transport (to calculate the use of sales volumes of products).

\section{Conclusions.}

In view of the above, it can be concluded that rationally organized local budgeting will contribute to the development of the region's well-being and to the improvement of the social standard of living of the population.

Analytical estimation of local taxes and fees is an important source of information on the state of payments with the state, and also enables the heads of governmental bodies to make appropriate decisions and influence the filling of local budgets. Timely and accurate information on local taxes and fees is necessary to analyze the performance of the enterprise, which will prevent errors in the future, will allow the enterprise to optimize the tax burden and to contribute to the development of the region, since taxes paid is one of the main sources of financing local budgets .

Therefore, local taxes and fees have a significant impact on the activity of the enterprise and the economic life of the region, so effective control over their formation and use is important for territorial communities and improvement of their living conditions. 


\section{References:}

1. Biudzhetnyi monitorynh: Analiz vykonannia biudzhetu za 2016. V.V. Zubenko, I.V. Samchynska, A.Yu. Rudyk; IBSED, Proekt «Zmitsnennia mistsevoi finansovoi initsiatyvy (ZMFI-II) vprovadzhennia», USAID. K: 2017. 64-69.

2. Yevropeiska khartiia mistsevoho samovriaduvannia : Mizhnarodnyi dokument vid 15.10.1985 URL: http://zakon2.rada.gov. ua/laws/show/994_036.

3. Mistsevi podatky (Tsentralnyi ofis reform pry minenerhorozvytku) 2018. URL: https://storage.decentralization. gov.ua/ uploads/library/file/261

4. Podatkovyi kodeks Ukrainy vid 02.12.2010 № 2755-VI stanom na 15.04.2018. URL: http:// zakon2.rada.gov.ua/laws/show/2755-17

5. Pro vnesennia zmin do Podatkovoho kodeksu Ukrainy ta deiakykh zakonodavchykh aktiv Ukrainy shchodo zabezpechennia zbalansovanosti biudzhetnykh nadkhodzhen u 2017 rotsi: Zakon Ukrainy vid 20.12.2016 № 1791-VIII, stanom na 15.04.2018. URL: http://zakon5.rada.gov. ua/laws/show/1791-19/page

6. Sait Fiskalnoi sluzhby Ukrainy. URL: http:// sfs.gov.ua/

7. Turystychnyi zbir - bonus dlia mistsevykh biudzhetiv. URL: http://cost. ua/news/747-turystychnyy-zbir-bonus-dlya-mistsevykh-byudzhetiv

\section{Література:}

1. Бюджетний моніторинг: Аналіз виконання бюджету за 2016 рік / В.В. Зубенко, І.В. Самчинська, А.Ю. Рудик [та ін.] ; ІБСЕД, Проект «Зміцнення місцевої фінансової ініціативи (ЗМФІ-ІІ) впровадження», USAID. K., 2017. 64-69.

2. Європейська хартія місцевого самоврядування : Міжнародний документ від 15.10.1985. URL: http://zakon2.rada.gov. ua/laws/show/994_036.

3. Місцеві податки (Центральний офіс реформ при міненергорозвитку) 2018p. URL : https://storage.decentralization. gov. ua/uploads/library/file/261

4. Податковий кодекс України від 02.12.2010 № 2755-VI станом на 15.04.2018 URL: http://zakon2.rada.gov. ua/laws/show/2755-17.

5. Про внесення змін до Податкового кодексу України та деяких законодавчих актів України щодо забезпечення збалансованості бюджетних надходжень у 2017 році: Закон України від 20.12.2016 № 1791-VIII, станом на 15.04.2018 URL: http://zakon5. rada.gov.ua/laws/show/1791-19/page.

6. Сайт Фіскальної служби України URL: http://sfs.gov.ua/.

7. Туристичний збір - бонус для місцевих бюджетів. URL: http://cost.ua/news/747turystychnyy-zbir-bonus-dlya-mistsevykhbyudzhetiv

ГУЧаленко Л.В., ДУбовСьКИЙ В.О. (2019). АНАЛІТИЧНА ОЦІНКА МІСЦЕВИХ БЮДЖЕТІВ ТА ЗБОРІВ І ЗАХОДИ ВДОСКОНАЛЕННЯ МЕХАНІЗМІВ ЇХ СПРАВЛЯННЯ. БІОЕКОНОНОМІКА ТА АГРАРНИЙ БІЗНЕС, 10(2): 36-42. http://doi.org//10.31548/ bioeconomy2019.02.036.

Анотація. У статті розглянуто вплив змін нормативно-законодавчої бази щодо місцевих податків і зборів. Окреслено значення місцевих бюджетів в бюджетній системі України. Акцентовано увагу на підвищенні ролі місцевих податків і зборів та збільшення їх частки у власних доходах місцевих бюджетів, як головного завдання фінансово-бюджетної політики держави. Виокремлено зміст статті 10 Податкового кодексу України яким встановлено перелік місцевих податків та зборів, виходячи з якого, кожна сільська, селищна чи міська рада 
приймає рішення щодо встановлення на своїй території тих чи інших місцевих податків та зборів. Приведено класифікацію місцевих податків (податок на майно, який складається із плати за землю, податку на нерухоме майно, відмінного від земельної ділянки, транспортного податку; єдиний податок)) та зборів (збір за місия для паркування транспортних засобів; туристичний збір). здійснено аналітичну оцінку структури місцевих податків та зборів України за 2016-2018 рр.. Акцентовано увагу, що в загальній структурі податкових надходжень місцевих бюджетів роль туристичного збору - незначна, однак спостерігається збільшені туристичного збору у м. Києві, м. Одесі, м. Львові та м. Харкові, які мають пам'ятки архітектури, рекреаційну інфраструктуру тощо. Аналіз надходження туристичного збору до бюджетів найпопулярніших українських курортів свідчить, що одноосібним лідером рейтингу є бальнеологічний курорт Трускавець. Найбільш відчутний вплив на доходи місцевих бюджетів туристичний збір має для с. Поляниця (гірськолижний курорт «Буковель»), с. Косонь (термальний курорт «Косино»), с. Новофедорівка (чорноморський курорт Залізний порт) та смт. Східничя (бальнеологічний курорт).

Запропоновано виокремлення додаткових механізмів і заходів, що сприятимуть вдосконалюванню наповнення дохідноїчастини бюджету окремих місцевих громад, регіону та країни в цілому.

Узагальнено, що своєчасна і достовірна інфоормація з обліку місцевих податків і зборів $є$ необхідною для аналізу результатів функціонування підприємства, що унеможливить виникнення помилок у майбутньому, надасть змогу підприємству оптимізувати податкове навантаження та зробити свій внесок у розвиток регіону, оскільки сплачені податки є одним з основних джерел фінансування місцевих бюджетів.

Ключові слова: місцеві податки та збори, місцеве оподаткування, місцевий бюджет, податок на майно, єдиний податок, плата за землю, транспортний податок, збір за місия для паркування транспортних засобів, туристичний збір, аналітична оцінка, менеджмент. 